\title{
A new species of Holostrophus (Paraholostrophus) (Coleoptera: Tetratomidae) from central Honshu island, Japan
}

\author{
Masahiro Saitô \& Ondřej Konvička
}

\begin{abstract}
A new species of Holostrophus (Paraholostrophus) (Coleoptera: Tetratomidae) from central Honshu island, Japan. - Acta Mus. Siles. Sci. Natur., 66: 1-5, 2017.

Abstract: A new species, Holostrophus (Paraholostrophus) toyoshimai sp. nov., is described from central Honshu, Japan. The new species is most similar to Holostrophus (Paraholostrophus) orientalis Lewis, 1895, but differs from the latter in morphology of male genitalia and coloration of elytra.
\end{abstract}

Keywords: Taxonomy, new species, Coleoptera, Tetratomidae, Holostrophus, East Palaearctic Region, Honshu island, Japan.

\section{Introduction}

The genus Holostrophus Horn, 1888 includes 19 species worldwide (Csiki 1924; Nikitsky 1998, 2007; Pollock 2012) and is divided into two subgenera - Holostrophus s. str. (7 species) and Paraholostrophus Nikitsky, 2007 (12 species) (Nikitsky 2007). Among them, two species, H. (Paraholostrophus) orientalis Lewis, 1895 and H. (Holostrophus) morimotoi Sasaji, 1974, have similar elytral maculation and are known from Japan. We had an opportunity to examine five specimens collected in central Honshu and recognized them as a distinct new species, described in this paper. Individuals of the new species have prothoracic hypomera with weak punctures and without obvious furrows between punctures; therefore, it is assigned to subgenus Paraholostrophus according to Nikitsky (2007).

\section{Materials and methods}

Abbreviations of morphological measurements used herein are as follows: L-length of body (= measured from apical margin of clypeus to apices of elytra); W- maximum width of body; FW-width across frons (= distance between eyes); ED-diameter of eye in frontal view; CL-length of clypeus; CW-width of clypeus; PL-length of pronotum; PW - width of pronotum; HW - width of cranium; EL - length of elytra; EW - width across humeri; MtiL-length of meta-tibiae; $1 \mathrm{MtaL}$-length of 1 st meta-tarsomere; AL-length of aedeagus. The average values of measurements are given in parentheses after the range.

Exact label data are cited for each type specimen. Additional remarks are given in square brackets. Individual lines on labels are separated by a single slash (/), and individual labels are separated by a double slash $(/ /)$. The holotype and paratypes are glued to cardboard plates. Information in quotation marks (" "') indicates the original spelling in the original description. Type specimens of the newly described species are provided with additional red labels with the following printed text: “Holostrophus / (Paraholostrophus) / toyoshimai sp. nov. / HOLOTYPUS [or] PARATYPUS, $\widehat{\jmath}$ [or] $q$ / des. Masahiro SAITÔ \& / Ondřej KONVIČKA, 2017 / オビモ ンヒメナガクチキ’.

Specimens used in this study are deposited in the following institutions and private collections (acronyms used in this paper are in parentheses):

(BMNH) - Natural History Museum, London, United Kingdom (Max Barclay);

(MSC) - Masahiro Saitô, private collection, Sakai-shi, Japan;

(NSMT) - National Museum of Nature and Science, Tsukuba, Japan (Shûhei Nomura);

(KTC) - Kentarô Toyoshima, private collection, Gifu-shi, Japan;

(OKC) - Ondřej Konvička, private collection, Zlín, Czech Republic. 


\section{Systematic part}

\section{Holostrophus (Paraholostrophus) toyoshimai sp. nov. (Figs. 1-6)}

[Japanese name: Obimon-hime-nagakuchiki]

Type locality: Japan, Honshu island, Gifu Prefecture, Shirakawa-mura, Ôshirakawa, 1210 m a.s.l.

Type material: Holotype: $\hat{\jmath}$, “岐阜県大野郡 / 白川村大白川 / 2016. 8/7 9/4 / 豊島健太郎採集 // Ôshirakawa / Shirakawa-mura / Gifu Pref., JPN / 7.VIII-4.IX.2016 / K. Toyoshima leg.” (NSMT) [1210 m a.s.l., in flight interception trap, text printed]. Paratypes: 1ㅇ, “岐阜県揖斐郡 / 久瀬村小津 / 18.JUL.2005 / 豊島健太 郎採集 // Ozu / Kuze-mura / Gifu Pref., JPN / 18.VII.2005 / K. Toyoshima leg.” (OKC) [440 m a.s.1., beating, text printed]; 19, “岐阜県高山市 / 新穂高温泉 / 15.AUG.2008 / 豊島健太郎採集 // Shinhodaka-onsen / Takayama-shi / Gifu Pref., JPN / 15.VIII.2008 / K. Toyoshima leg.’’ (MSC) [1330 m a.s.1., beating, text printed]; 1ㅇ, “岐阜県大野郡 / 白川村大白川 / 2000.8.20 灯火 / 豊島健太郎採集 // Ôshirakawa / Shirakawa-mura / Gifu Pref., JPN / 20.VIII.2000 / K. Toyoshima leg.” (KTC) [1210 m a.s.l., at light, text printed]; 19, “岐阜県郡 上市大 / 和町落部字黒田 / 2016.7/30 8/12 / 豊島健太郎採集 // Aza Kuroda, Ochibe / Yamato-cho, Gujyo-shi / Gifu Pref., JPN / 30.VII-12.VIII.2016 / K. Toyoshima leg.'” (BMNH) [750 m a.s.1., in flight interception trap, text printed].

Description. Body elongate oval, evenly rounded anteriorly, rather strongly convergent posteriorly, L/W $2.21(\mathrm{n}=1)$, gently arcuate sided, convex dorsally, shining, covered with thin and short whitish yellow lustered pubescence; legs and antennae densely covered with fine pubescence. Dorsal surface (Fig. 1) entirely brownish black, with obscurely dark reddish brown around the edge band incurvate at basal angle areas on pronotum and the following light yellowish orange markings: anterior band reaching base of elytra around scutellum and outer margins, with projection on anterior edge and two projections on posterior edge; a pair of cuneiform markings along suture in middle of elytra; a pair of subapical bands reaching outer margins; and short apical stripe reaching apex along suture; these elytral markings sometimes more extensive and partly connected by thin lines (Fig. 6); head and antennae dark orange; legs reddish brown. Ventral surface entirely dark orange; abdomen covered with fine yellowish brown pubescence.

Male. Head oval, densely and evenly punctate and densely microsculptured; frons slightly convex and elongate, FW/ED $1.38(\mathrm{n}=1)$; frontoclypeal furrow indistinct, front margin straight; clypeus trapezoidal, CW/CL $1.60(\mathrm{n}=1)$, front margin straight. Eyes longitudinally elongate oval in lateral view, emarginate at antennal insertions. Terminal maxillary palpomere (Fig. 4) rather weakly broadened apically; outer margin about 1.3 times as long as inner margin $(n=1)$; apex straight, somewhat longer than inner margin. Antennae (Fig. 2) weakly elongate clavate, reaching hind angles of pronotum; terminal antennomere spindle-shaped; relative lengths of each antennomere from base to apex $(n=1): 1.13,0.68,1.00,0.65,0.68$, $0.65,0.65,0.61,0.55,0.61,1.77$; relative length to width ratio of each antennomere from base to apex $(\mathrm{n}=1): 1.75,1.50,2.21,1.33,1.31,1.00,0.87,0.68,0.55,0.50,1.83$.

Pronotum semicircular in dorsal view, PW/PL $0.63(\mathrm{n}=1)$, PW/HW $1.63(\mathrm{n}=1), \mathrm{PW} / \mathrm{EW}$ $1.02(\mathrm{n}=1)$, widest at base; around the edge distinctly and narrowly bordered; anterior angles absent; basal angles slightly and roundly produced backward; basal margin weakly sinuate in middle; disc densely and finely punctate and densely microsculptured, with pair of linear basal foveae along the posterior margin. Scutellum semicircular, parallel-sided, roughly punctate and microsculptured.

Elytra elongate oval, slightly arcuate on sides, widest at base, convergent posteriorly from base; EL/W $1.60(n=1)$; disc densely and finely punctate and densely microsculptured.

Ventral surface closely punctate and densely microsculptured, rather sparsely on metaventrite; prosternal process (Fig. 5) before apex 1.27 times $(n=1)$ as wide as narrowest interval of procoxal cavities; 5 th ventrite widely rounded on apex. 


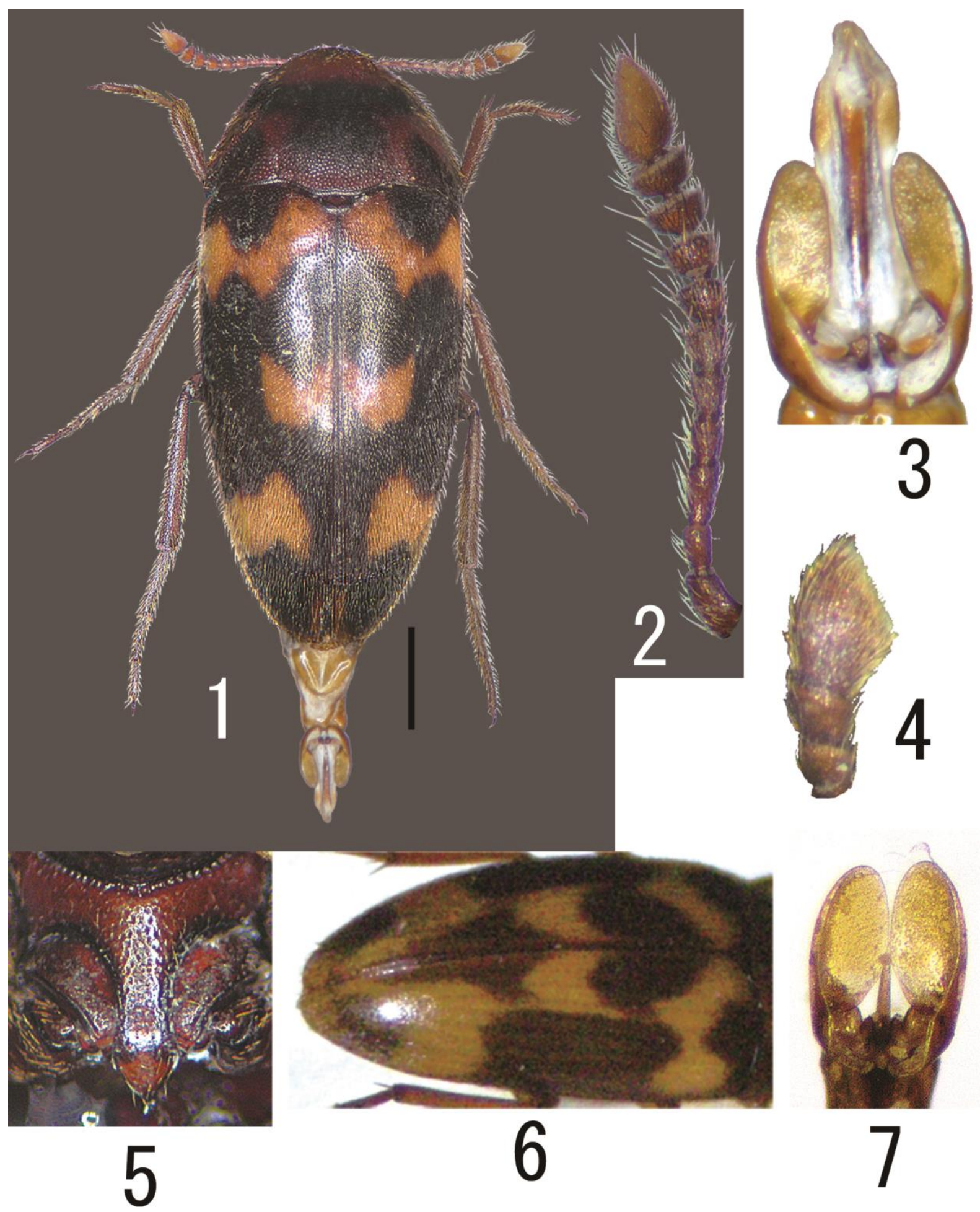

Figs 1-7: 1-6. Holostrophus (Paraholostrophus) toyoshimai sp. nov. (1-5, holotype); 7. H. (P.) orientalis (from Honshu island, Japan); 1. habitus in dorsal view; 2. left antenna; 3. lobes of paramere and apex of aedeagus in dorsal view; 4. maxillary palpus; 5 . prosternal process; 6 . variation of elytral markings; 7 . lobes of paramere in dorsal view. Scale: $1.0 \mathrm{~mm}$. 
Aedeagus (Fig. 3) elongate, AL/EL about $0.3(\mathrm{n}=1)$, AL/AW about $3.1(\mathrm{n}=1)$; parameres with pair of lobes, lobe 2.54 times $(n=1)$ as long as wide; median lobe elongate, smaller and rounded in dorsal view and curved downward in lateral view at apex.

Legs slender, MtiL/EL about $0.4, \mathrm{MtiL} / \mathrm{W}$ about 0.6 , $1 \mathrm{MtaL} / \mathrm{MtiL}$ about 0.4 , relative lengths of each hind tarsomere from base to apex $(\mathrm{n}=1): 1.00,0.42,0.32,0.55$.

Female. L/W 2.19-2.26 (2.22, $\mathrm{n}=4)$; EL/W 1.67-1.70 $(1.68, \mathrm{n}=4)$; frons wider, FW/ED 1.56-1.81 (1.64, $\mathrm{n}=4)$; pronotum wider, PW/HW 2.53-2.64 (2.58, $\mathrm{n}=4)$; PW/EW 1.00-1.01 $(1.01, \mathrm{n}=4)$. Relative lengths of each antennomere from base to apex $(\mathrm{n}=1): 1.56,0.83,1.00$, $0.83,0.72,0.83,0.72,0.72,0.72,0.78,2.11$; relative length to width ratio of each antennomere from base to apex $(\mathrm{n}=1): 1.65,1.43,1.80,1.50,1.24,1.07,0.81,0.68,0.57,0.61,1.81$. 5th ventrite widely rounded on apex. 1MtaL/MtiL 0.40-0.46 $(0.44 \mathrm{n}=4)$, relative lengths of each hind tarsomere from base to apex $(\mathrm{n}=1): 1.00,0.40,0.33,0.53$.

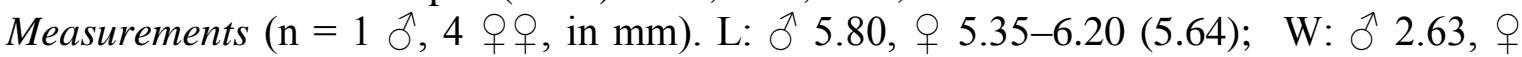
$2.28-2.80(2.53)$.

Distribution. Gifu Prefecture, central Honshu, Japan.

Bionomy. Unknown.

Collection circumstances. Type specimens were captured in flight interception traps, by beating and at light. The type locality is a beech forest at $1330 \mathrm{~m}$ a.s.1.

Etymology. The species is dedicated in honor to Mr. Kentarô Toyoshima, who collected the type specimens.

Differential diagnosis. Holostrophus (Paraholostrophus) toyoshimai sp. nov. morphologically resembles H. (Paraholostrophus) orientalis and is distinguished from the latter by the following characters: 1) the lobes of parameres in male about 2.5 times as long as wide, while about 2.0 times in $H$. orientalis (Fig. 7); and 2) the projections of anterior margin of the anterior band on elytra not reaching the base of elytra and the black areas at base of elytra are not divided, while the band reaches the base and the black areas at base of elytra are divided. Lewis (1895) wrote in the original description of $H$. orientalis: "In one example the dusky spots at the base of the elytra join", therefore it seems that the specimen might belong to $H$. toyoshimai sp. nov. This new species is also similar to $H$. (P.) minimus Nikitsky, 1998 from Philippines, but distinguished from the latter in having short prosternal process with rounded apex, a transverse spot in middle of elytra and small body $(3.5 \mathrm{~mm})$ in the latter.

Acknowledgements: We would like to thank Lukáš Sekerka (Praha, Czech Republic) for comments on the manuscript and correction of English; Darren Pollock (Portales,New Mexico, USA) and Josef Jelínek (Praha, Czech Republic) for valuable comments on and corrections to the manuscript; Kentarô Toyoshima (Gifu-shi, Gifu Pref., Japan) for providing specimens for study and this description.

\section{References}

Csiki E. (1924): Serropalpidae. Pp. 1-62. In: Schenkling S. (ed.): Coleopterorum Catalogus. Pars 77. W. Junk, Berlin, $62 \mathrm{pp}$.

Lewis G. (1895): On the Cistelidae and other heteromerous species of Japan. - Annals and Magazine of Natural History (6) 15: 250-278, 422-448, pl. 8.

Nikitsky N.B. (1998): Generic classification of the beetle family Tetratomidae (Coleoptera, Tenebrionoidea) of the world, with description of new taxa. Pensoft, Sofia-Moscow, $80 \mathrm{pp}$.

- (2007): The beetles of the genus Holostrophus Horn, 1888 (Coleoptera, Tetratomidae, Eustrophinae, Holostrophini) of the world fauna. - Byulleten' Moskovskogo Obshchestva Ispytatelei Prirody Otdel Biologicheskii 112(1): 13-30 (in Russian, English summary).

Pollock D.A. (2012): Review of the Eustrophinae (Coleoptera, Tetratomidae) of America north of Mexico. ZooKeys 188: 1-153. 
Authors' addresses: Masahiro Saitô, 4-3-23-115 Mikuni-higashi, Mikuni-chô, Sakai-shi, Fukui Pref., 913-0016 Japan

E-mail: heteromerasaito@fork.ocn.ne.jp

Ondřej Konvička, Kúty 1959, CZ-760 01 Zlín, Czech Republic\& Institute of Entomology, Biology Centre AS CR, Branišovská 31, CZ-370 05 České Budějovice, Czech Republic

E-mail: brouk.vsetin@centrum.cz 